\title{
The Effect of an Accidental Carrier Rocket Crash on Soil and Vegetation Cover
}

\author{
Balgabay S. Maikanov' ${ }^{1}$ Laura T. Auteleyeva'* ${ }^{1 *}$ Zhailaubay K. Zhubatov², \\ Askar A. Terlikbayev³, Kanat M. Kamsaev³ \\ 1 Department of Veterinary Sanitation, Faculty of Veterinary Sciences and Animal Husbandry, Saken Seifullin \\ Kazakh Agro Technical University, 62 Zhenis Avenue, Nur-Sultan, 010011, Republic of Kazakhstan \\ 2 LLP Institute of Innovative Research and Technology, 8 Microdistrict, 28 Auezov District, Almaty, A10A7K2, \\ Republic of Kazakhstan \\ 3 Department of Veterinary Medicine, Faculty of Veterinary Sciences \& Animal Husbandry, Saken Seifullin \\ Kazakh Agro Technical University, 62 Zhenis Avenue, Nur-Sultan, 010011, Republic of Kazakhstan \\ * Corresponding author's e-mail: zavetovm@mail.ru
}

\begin{abstract}
The dynamics of the consequences of the Proton-M carrier rocket crash on the soil and vegetation cover in the area where its parts fell were studied in 2007-2014. Analytical methods such as liquid chromatography with electrochemical and spectrophotometric detection were used. In 2007, four soil detoxifications were performed. A second study in 2009 showed a sharp increase in the area of contamination of plants by UDMH (unsymmetrical dimethylhydrazine) and NDMA (N-Nitrosodimethylamine). In 2010, the situation shifted in the opposite direction. Toxicants in plants were absent for three years (2010-2012) but reappeared in 2013 and 2014. The accidental crash of the Proton-M carrier rocket led to the destruction of the soil and vegetation cover, ignition of vegetation, and soil contamination. In the area where the rocket parts fell, the UDMH content in the soil was 1.4-5,200 times higher than the threshold limit value. The fall of the carrier rocket increased the area of soil contamination with UDMH to $3,600 \mathrm{~m}^{2}$, with NDMA to $917 \mathrm{~m}^{2}$, and with nitrate ions to $8,314 \mathrm{~m}^{2}$. The reappearance of heptyl and nitrous compounds in plants and soil was detected four years after repeated detoxification of the soil.
\end{abstract}

Keywords: UDMH, NDMA, carrier rocket Proton-M, Baikonur, liquid chromatography, electrochemical and spectrophotometric detection.

\section{INTRODUCTION}

The Soviet launching area in Kazakhstan, the Baikonur launching area, occupies a special place in the history of rocket production and space industry. The first intercontinental ballistic missile P-7 successfully launched in August 1957 and reached the Kamchatka Peninsula which at a distance of six thousand kilometers. Six weeks later, the modified P-7 placed the first artificial satellite of the Earth-satellite into. In 1961, the first cosmonaut Yuri Gagarin began his space journey from the same launch pad (Gruntman, 2019).

In 2007, there was detected an emergency shutdown of the 2 nd stage engine of Proton-M LV at the launch of spacecraft (SC) JC Sat-11. A cluster consisting of the second and third stages, the upper stage and the spacecraft fell in the Ulytau district of the Karaganda region of the Republic of Kazakhstan. In the event of accidental falls of the Proton LV, a large-scale of the environmental impact is observed at the initial stage of a flight. The nature of the impact is determined by the structural failure mode. The maximum mechanical and pyrogenic damage of the ecosystems occurs when the LV falls with an explosion on the ground. The destruction of a falling structure on the ground, not accompanied by an explosion and fire, leads to long-term chemical pollution of the ecosystems (Koroleva et al., 2015). 
The difficulty in determining the environmental damage during the fall of a life rocket lies in the impossibility of preliminary collection of the characteristics of the affected area and the variety of possible consequences of the fall of an emergency product. From this, it follows that in determining the amount of the environmental damage it is necessary to consider many different options for landscape disturbance (Ruzmetova and Plaksitsky, 2017).

The environmental monitoring system, the system for developing design and construction solutions for a worked-out stage, and single feedback system "OS + launching area environmental monitoring system + system for design and construction solutions" are applied at the launching area Vostochny to form optimal ways of changing the design and construction parameters of the OS for management of its fire and explosion hazard in various areas of the environment. The article considers the problem of the technogenic impact of launching vehicles (LV) with the main liquid engines on various parts of the environment. It has been shown that the fire hazardous effect of the fuel residues in the spent stage tanks increases the level of ecosystem disturbance for the ecosystem of the affected area. There were made suggestions for selecting technologies, schematic and design solutions of the operating system based on the system analysis, aimed at increasing fire and explosion safety during the development of LV stages using basic liquid propulsion systems (Trushlyakov et al., 2016).

The release of highly toxic rocket fuel 1,1-dimethylhydrazine (UDMH) and its products into the environment represents a serious negative impact on the ecosystem, as well as on human health. This study demonstrates the first data on the spatial distribution and quantitative determination of UDMH and its main conversion products (methylhydrazine, hydrazine, 1,1,4,4-tetramethyltetrazene, formaldehyde, acetaldehyde and furaldehyde $N, \mathrm{~N}$-dimethylhydrazine, 1-formyl-2,2 -dimethylhydrazine, $N, N$-dimethylformamide, $N$-nitrosodimethylamine, and 1-methyl-1H-1,2,4-triazole) in the peat-bog soil of the fall site in the subarctic region. Using the previously developed methodology, one hundred soil samples from peat bogs and a surface water sample were analyzed. The data set covers the results of a study of 96 samples of peat bog soil from the fall place of the first stage of the Cyclone-3 launch vehicle contained unburned toxic rocket fuel 1,1-dimethylhydrazine (UDMH) in the European North of Russia. Soil samples were taken during a helicopter expedition to the "Koida" fall region of the Plesetsk Cosmodrome operation zone in October 2015 at different distances from the center of the fall site and different soil horizons (Ul'yanovskii et al., 2020).

According to some scientists, the problems of emergency launches of man-carrying rockets arise due to many reasons that have huge negative consequences on the environment (Cohen and McCarthy, 2015; Federal Aviation Administration, 2016; Barmin et al., 2018; Bolodyanet al., 2018; Veniaminov et al., 2018; Dek et al., 2020).

\section{MATERIALS AND METHODS}

Samples collected in 2007-2014 (842 soil samples and 916 plant samples) were used for the analysis. The studies were conducted in the research center "Garysh-Ekologiya" in Almaty and the analytic laboratory "Garysh-Ekologiya" in Almaty and Zhezkazgan.

\section{Chemical analyses}

Determination of the mass fraction of unconsolidated NDMA in samples of soft plant parts. The method is based on the extraction of NDMA from plants using a hydrochloric acid solution. Then it is distilled from the obtained extract and analyzed using reversed-phase chromatography with spectrophotometric detection of NDMA at a $240 \mathrm{~nm}$ wave-length. Equipment: liquid chromatography "Stayer-UV/VIS" (Research and Production Company "Akvilon" CJSC, Moscow, Russia).

Determination of the mass fraction of mobile forms of 1,1-dimethylhydrazine in soil samples. The method is based on the extraction of mobile forms of UDMH from the soil using $1 \mathrm{~mol} / \mathrm{l}$ hydrochloric acid. Then 1,1-dimethylhydrazine is distilled with steam into an acid solution. The distillation product is analyzed using ion chromatography with amperometric detection. The peak area of 1,1-dimethylhydrazine is proportional to its concentration. Equipment: liquid chromatography "Tsvet Yauza" with an electrochemical detector complete with a PCIBMAT-type computer and corresponding software.

Determination of the mass fraction of unconsolidated UDMH in samples of soft plant parts using ion chromatography with amperometric 
detection. Unconsolidated 1,1-dimethylhydrazine is isolated from the soft parts of plants using $1 \mathrm{~mol} / \mathrm{l}$ hydrochloric acid. After alkalization, from the obtained extract, 1,1-dimethylhydrazine is distilled into an acid solution with steam. The distillation product is analyzed using ion chromatography with amperometric detection at the oxidation potential of the analyte. Calculations are carried out using the external standard method based on the peak area. Equipment: liquid and ion analytical small-size chromatograph "Tsvet Yauza" (MEKV. 414538.001 PS) with an amperometric detector complete with PCIBMAT-type computer and corresponding software according to Technical Specifications 4215-005-05771185-2001.

\section{Determination of the mass concentration of 1.1-dimethylhydrazine in a biological medium}

The method is based on the preliminary separation of milk proteins and fats from an acidic medium, alkalization of the filtrate, steam distillation of 1,1-dimethylhydrazine into an acid solution, and subsequent analysis of distillation product using ion chromatography with amperometric detection. The peak area of UDMH is proportional to its concentration. The proportionality factor is set during the calibration of the chromatograph. Equipment: liquid and ion analytical small-size chromatograph "Tsvet Yauza" (MEKV. 414538.001 PS) with an electrochemical detector complete with a PCIBMAT-type computer and corresponding software.

\section{RESULTS AND DISCUSSION}

During the environmental study of the impact site in 2007, three areas were identified, which were contaminated with propellant components and their transformation products. The highest soil contamination was detected in the impact site of the upper part of the space tug and the transfer module of the spacecraft.

In this area, an excess of permissible level of UDMH contamination in the soil by a factor of 1.4 to 5,200 was detected (threshold limit value (TLV) is $0.1 \mathrm{mg} / \mathrm{kg}$ ). UDMH is a dangerous chemical substance with a carcinogenic effect (Pohanish, 2017). NDMA was identified in all soil samples from this region at levels ranging from 0.6 to $105.0 \mathrm{mg} / \mathrm{kg}$. Tetramethyltetrazene was not found in soil samples. An excess of permissible level of nitrate ions contamination by 2.0 to 19.95 times was detected. The highest content of nitrate-ion (TLV is $130 \mathrm{mg} / \mathrm{kg}$ ) was found in a soil sample taken at the center of the rocket fragment impact site and in a soil, sample taken at a distance of $3 \mathrm{~m}$ south from that zone. The area of soil contamination was 3,600 $\mathrm{m}^{2}$ for UDMH, $917 \mathrm{~m}^{2}$ for NDMA, and $8,314 \mathrm{~m}^{2}$ for nitrate ion.

Vegetation contamination was generally not observed; UDMH in concentrations from 0.14 to $0.21 \mathrm{mg} / \mathrm{kg}$ was found only in three samples of plants taken in the center of the impact site.

In the period from 10 to 18 of September 2007 , the first detoxification was carried out using a 5\% aqueous solution of potassium permanganate, which was accompanied by a decrease in the concentration of UDMH in the soil by a factor of 1.57 and NDMA by a factor of 4.62 .

After the second detoxification (September $24,2007)$, the concentration of UDMH in the soil decreased by a factor of 5.68 compared with the level after the first treatment and the concentration of UDMH decreased a factor of 19.9. One month after the third detoxification (November $1,2007)$, the maximum concentration of UDMH reached $13.0 \mathrm{mg} / \mathrm{kg}(130 \mathrm{TLV})$ and the concentration of NDMA was $4.03 \mathrm{mg} / \mathrm{kg}$ (403 TLV). After the fourth detoxification, which was carried out at the end of the year, UDMH in the surface soil layer $(0-20 \mathrm{~cm})$ was not detected in most samples but was present at a depth of $40-80 \mathrm{~cm}$ at the levels up to 3 TLV (Fig. 1, 2).

Four years later, the studies revealed traces of seven UDMH derivatives in the soil: NDMA, dimethylamine (DMA), methyltriazole (MT), dimethyltriazole (DMT), dimethylformamide (DMF), dimethylamino-acetonitrile (DMAACN), formaldehyde, and nitrate ions.

Against the background of a general decrease in the level of soil contamination, signs of preservation of the general destruction of soil microflora were observed. Soil samples were recognized as phytotoxic.

Chemical analysis established the contamination of Anabasis salsa and Artemisia absinthium with UDMH and NDMA. The general state of the vegetation cover is shown in Figure 3. This vegetation predominates in the region.

The vegetation in the region of the rocket crash is represented by sparse pigweeds and wormwood associations. A typical plant on the highly saline soils $(50-100 \mathrm{mg} / \%$ of salts) is 


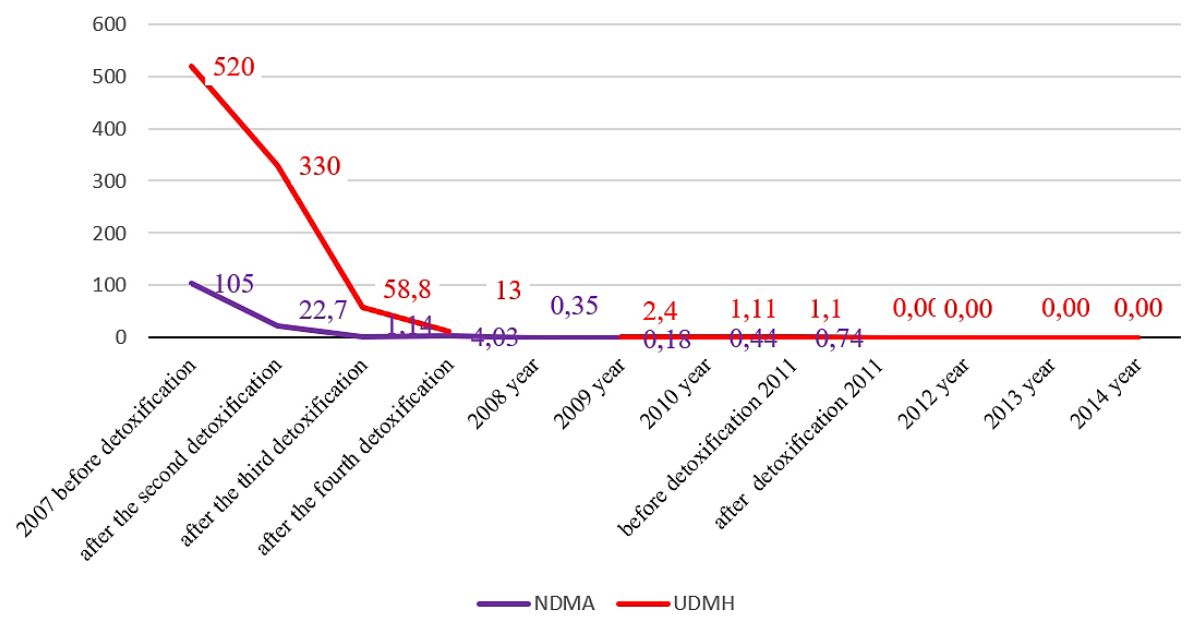

Figure 1. Type your title here. Obtain permission and include the acknowledgement required by the copyright holder if a figure is being reproduced from another source

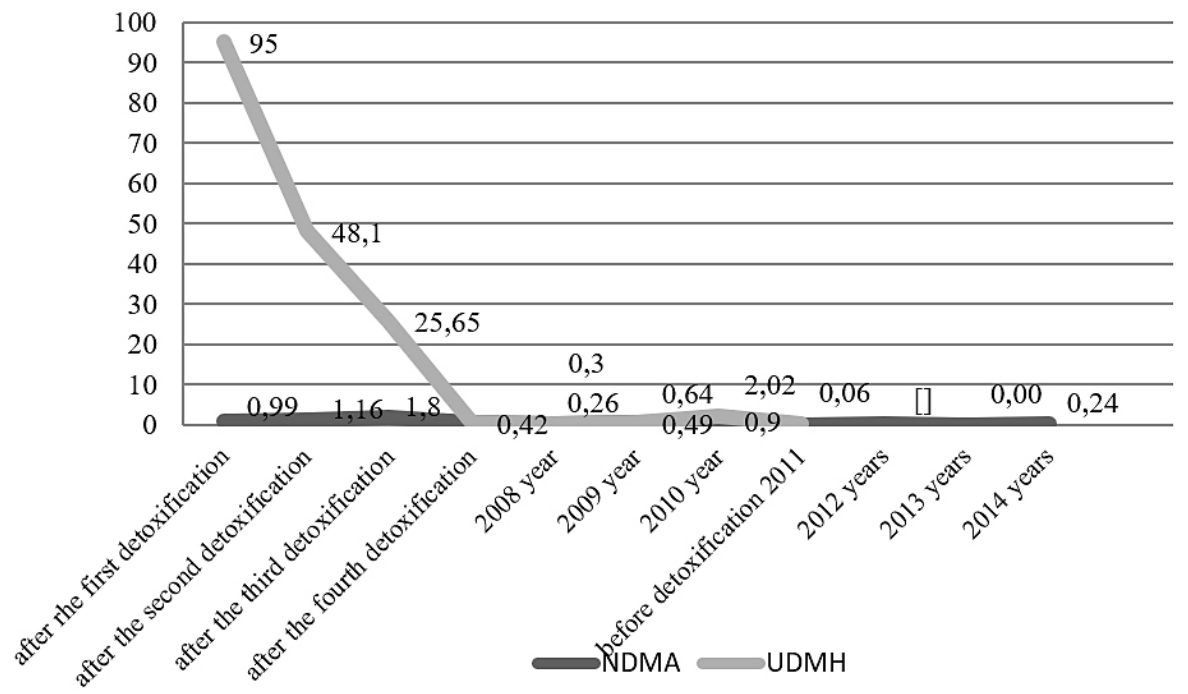

Figure 2. Dynamics of UDMH and NDMA soil contamination in the impact site of the upper part of the space tug and the transfer module of the spacecraft in 2007-2014: bottom - 40-80 cm soil layer

Anabasis salsa, a dwarf shrub from the Chenopodiaceae family $10-40 \mathrm{~cm}$ in height (Fig. 4). It vegetates in March, blooms in July, and bears fruit in September. It has a wide range of toleration of soil salinity and soil texture. It grows on gray-brown, brown alkaline, takyr-like, and gypseous gray soils with different types of mechanical composition, preferably halomorphic soils with an alkaline reaction. It forms monodominant communities over large areas in such conditions.

The root system is located in the uppermost 10 -cm layer, where about $85 \%$ of the total weight of the roots is located and only individual roots grow deeper. The taproot grows no deeper than $10 \mathrm{~cm}$ and stops growing at this level, its lateral roots grow horizontally at a depth of $50 \mathrm{~cm}$. This is an important forage plant for live-stock animals, especially camels. Anabasis salsa is used during winter for feeding live-stock animals.

The root system of Artemisia absinthium is more aggressive and is characterized by a powerful taproot that goes deep into the soil. Artemisia absinthium does not accumulate salt (Sharifivash and Shokrpour, 2017).

Of particular interest is the change of the area of vegetation contamination with UDMH and NDMA (Fig. 5). The total area of soil contamination in 2007 was $3,600 \mathrm{~m}^{2}$ and the area of contamination with UDMH and its transformation product NDMA increased by a factor of 700 after detoxification.

Moreover, in 2009, there was a sharp increase in the area of vegetation contamination 


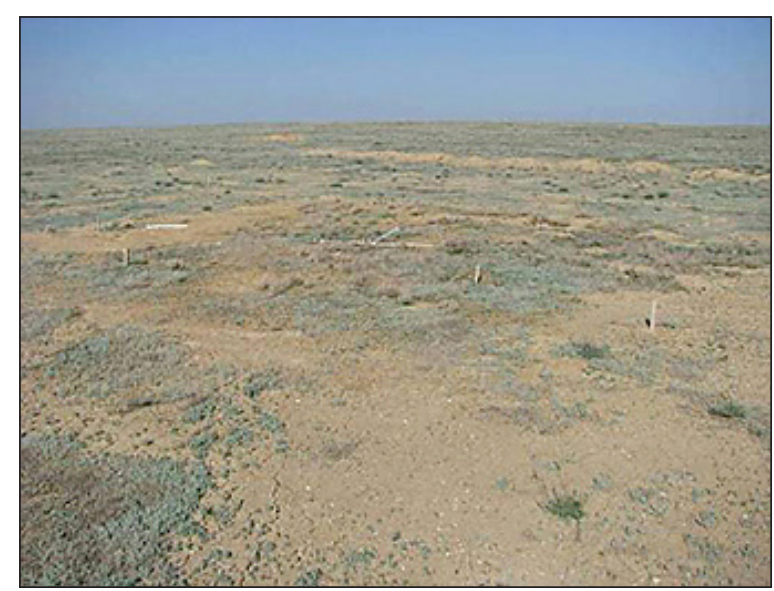

Figure 3. The state of the vegetation cover in the impact site of the upper part of Briz-M space tug and the transfer module

with UDMH with a smaller increase of NDMA contamination. However, in 2010, the situation shifted in the opposite direction - there was a predominance of nitrous contamination. At the same time, soil samples taken together with plants showed the absence of such contamination. The highest values of vegetation contamination by UDMH and NDMA were 1.5 and $13.05 \mathrm{mg} / \mathrm{kg}$, respectively. There were no TLV of these compounds in plants. An environmental study in the following years showed a sharp decrease in the vegetation contamination area.

In 2013, contamination with UDMH was detected in 5 plant samples at the levels from 0.16 to $0.919 \mathrm{mg} / \mathrm{kg}$. NDMA was detected in 12 plant samples at concentrations of $0.127-4.839 \mathrm{mg} / \mathrm{kg}$. In 2014, plant contamination with UDMH was observed within a radius of 5-10 $\mathrm{m}$ from the center of the rocket crash and contamination with

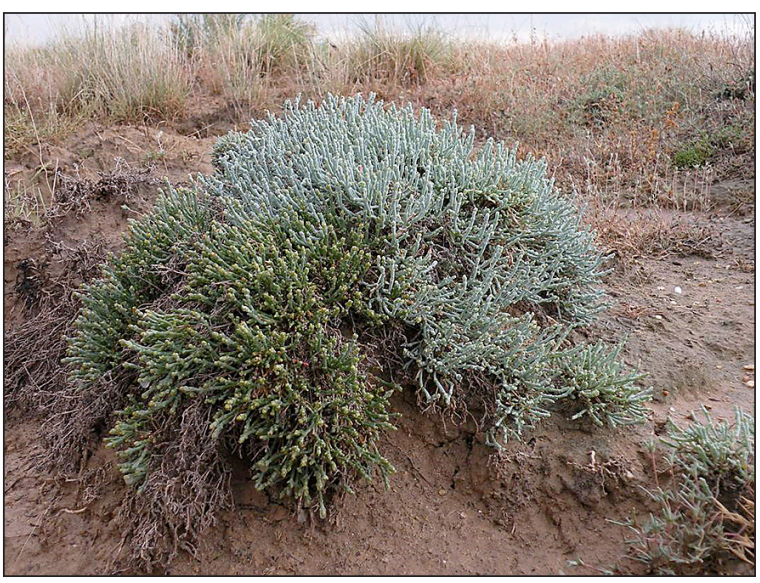

Figure 4. Habit view of Anabasis salsa

NDMA was observed within a radius of $10-30 \mathrm{~m}$ (Table 1 and Fig. 6).

The data in Table 1 describes the dynamics of the appearance of toxicants in plants: they were absent for two years (2010-2012) but reappeared in 2013 and 2014. The increase in the content of UDMH in 2014 compared to 2013 was $263 \%$ and for NDMA, it was $315.9 \%$. Therefore, an accidental crash of a carrier rocket, accompanied by an air-ground explosion, led to the disruption of the soil and vegetation cover, ignition of vegetation, contamination of the soil in the area where the rocket parts fell, an increase in the area of contamination of the vegetation cover, and the reappearance of heptyl and nitrous compounds in plants and soil, even after multiple detoxifications using potassium permanganate.

The available literature data do not explain the sharp increase of the area of vegetation contamination with toxic compounds in the areas of emergency heptyl spill 2-3 years after the soil was subjected to almost complete detoxification.

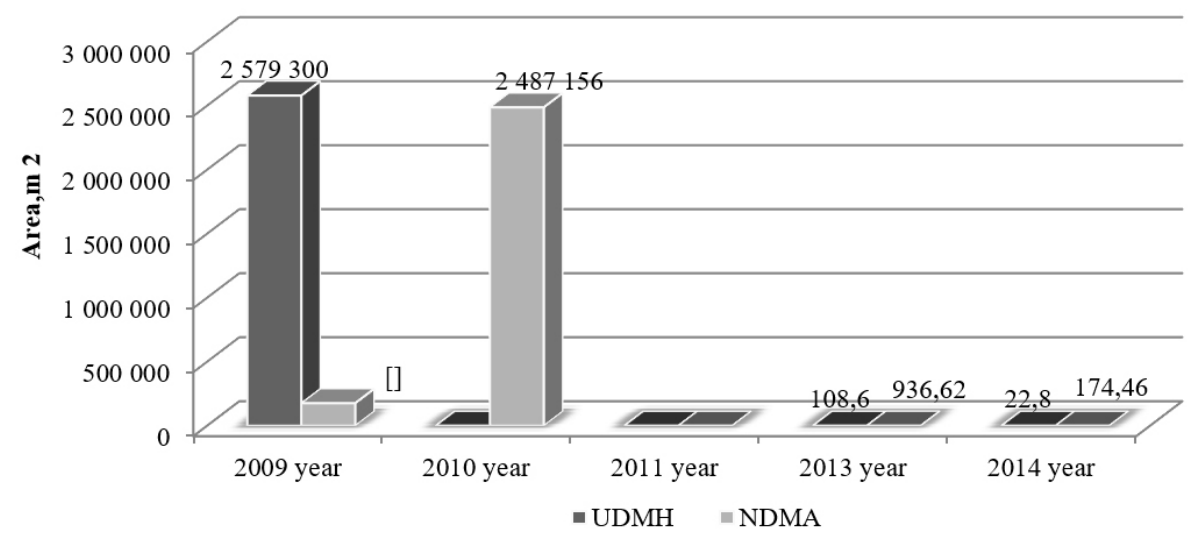

Figure 5. Dynamics of vegetation contamination with UDMH and NDMA in the impact site of the upper part of the space tug and the transfer module in 2009-2014 
Table 1. Maximum concentrations of UDMH and NDMA in plants in 2009-2014

\begin{tabular}{|c|c|c|}
\hline Year & UDMH $(\mathrm{mg} / \mathrm{kg})$ & NDMA $(\mathrm{mg} / \mathrm{kg})$ \\
\hline 2009 & 1.9 & 0.44 \\
\hline 2010 & $\mathrm{n} / \mathrm{d}$ & 6.9 \\
\hline 2011 & $\mathrm{n} / \mathrm{d}$ & $\mathrm{n} / \mathrm{d}$ \\
\hline 2012 & $\mathrm{n} / \mathrm{d}$ & $\mathrm{n} / \mathrm{d}$ \\
\hline 2013 & 0.19 & 4.13 \\
\hline 2014 & 0.5 & 13.05 \\
\hline
\end{tabular}

In studies of the rocket crash sites with peat soil in the subarctic significant quantities of UDMH and most products of its transformation were found at a distance less than $10 \mathrm{~m}$ from the center of the falling area. The maximum concentration of UDMH was found near the center, where the maximum permissible concentration (MPC) was exceeded by 2,400 times the MPC after 14 years from the moment the rocket fell (Ul'yanovskii et al., 2020).

It can be assumed that the increase of the area of vegetation contamination with UDMH and the product of its degradation NDMA occurred due to the water load of the detoxicant, which led to horizontal and vertical migration of the aqueous solution with UDMH and NDMA in the soil. Also, a well-developed root system of plants could contribute to the accumulation of toxicants. The vegetation represented by Anabasis salsa actively absorbed aqueous salt solutions and toxic compounds in small concentrations from the

a)

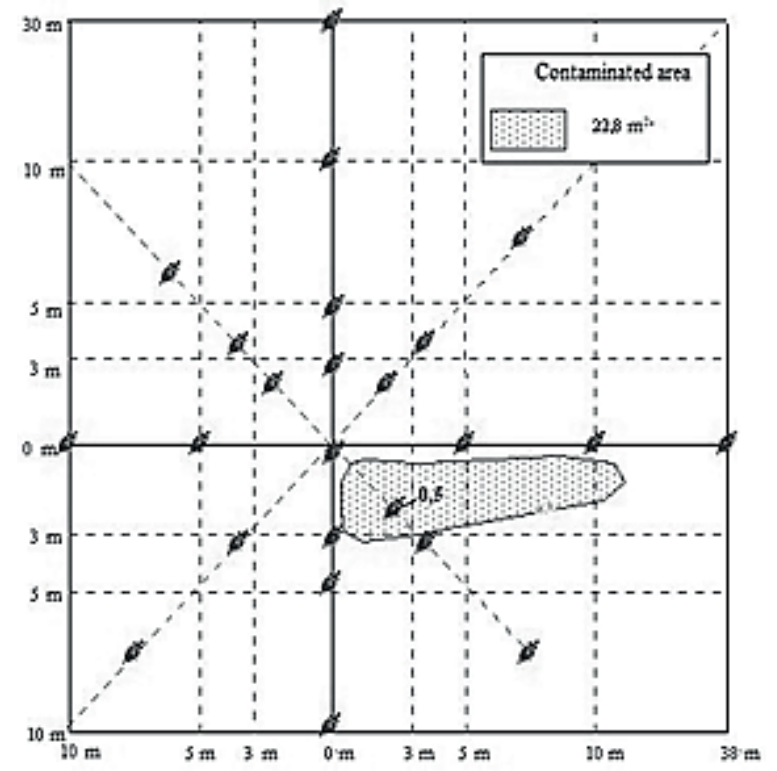

surface soil layer (clay loams inhibit the entry of water into the soil) and actively propagated and occupied new territories of the river basin of the Kumola River. The surface migration rate of UDMH was low, which was due to the plain terrain with a slight slope towards the river. This is evidenced by the growth of plants contaminated with UDMH and NDMA 10 and $30 \mathrm{~m}$ away from the centers of the rocket fragments impact sites, respectively.

The long-term reappearance of pollutants can be associated with the pelitic texture of soils that retain residual quantities of detoxicant. It can also be assumed that reappearance of UDMH and NDMA in soil and plants even seven years after the accident was due to the processes of transformation of nitrogen-containing compounds.

The chemistry of the processes of the transition of nitrates and nitrites to N-nitroso compounds in the presence of amines is well-known. In the environment (in surface waters and soil), nitrate and nitrite ions can form from ammonium ions $\left(\mathrm{NH}_{4}\right)$ as a result of biological oxidation (nitrification).

It has been suggested that under slightly acidic conditions, tertiary amines also react with nitrous acid to form nitrosoamines. The reactions between nitrites and various methylamines were studied and, in all cases, the formation of NDMA was established (Zarei et al., 2016; Kosyakov et al., 2019; Milyushkin et al., 2019; Liao

b)

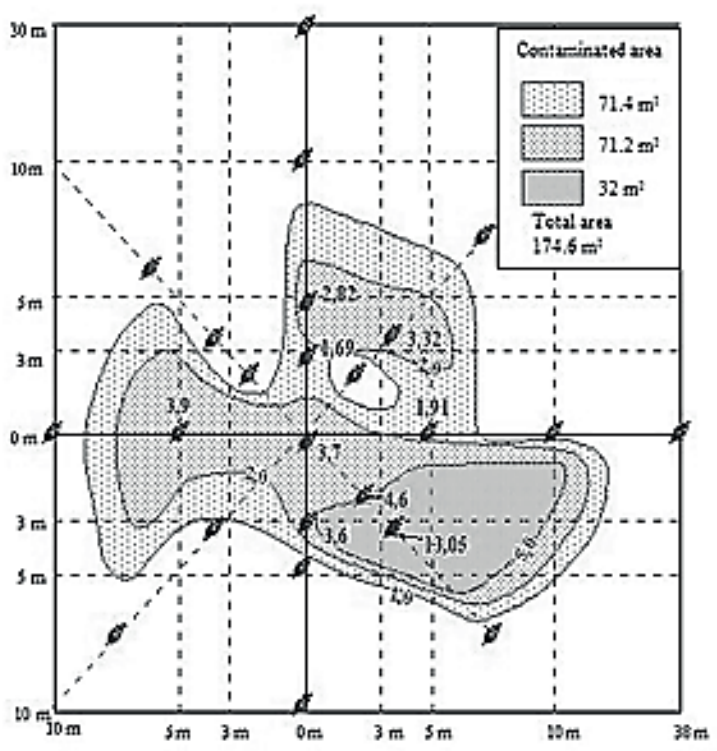

Figure 6. Area and level of vegetation contamination with UDMH (a) and NDMA (b) in the impact site of the upper part of the space tug and the transfer module in 2014 
et al., 2019; Huang et al., 2019). Chloride and bromide ions can be catalysts for the formation of N-nitroso compounds from secondary amines and nitrites. Roller and Keefir discovered that a noticeable increase in the rate of formation of NDMA from dimethylaniline and nitrite occurs in the presence of certain carbonyl compounds and at a $\mathrm{pH}$ above 3.0. The most effective catalyst is formaldehyde. It acts even at $\mathrm{pH}=9.0$.

After the reappearance of UDMH in plants in 2013-2014, we conducted research expeditions to examine farms adjacent to the accident site and to study the quality of milk from cows at these farms as the most likely toxicological contamination object.

Environmental safety issues are among the main subjects of discussion in space and rocket industry. First of all, this concerns the use of hazardous chemicals of the first and second hazard categories in the preparation and launch of rocket and spacecraft. The greatest environmental risks arising from the use of UDMH, a substance of the first hazard category, which is used as a component of rocket fuel in Proton-class carrier rockets. However, despite the low probability of accidents involving UDMH spills, the environmental damage from such accidents can be substantial. In our previous research the results of amino-acid composition of protein in cow's milk which were selected from farms adjoining to the territory of a falling of the RC "Proton-M" of the Ulytau area, Karaganda region of the Republic of Kazakhstan. According to the research, it was established that reliable differences were compared with the normal values in the content of all irreplaceable and replaceable amino acids in tests of a milk protein. The sum of amino acids of milk protein was $12.2 \%$ lower in comparison with the normal values. The limiting amino acids in the studied milk were methionine+ cysteine and phenylalanine + tyrosine (Maikanov and Auteleyeva, 2018).

The author of this article, based on twenty months of the field research and key interviews with the environmental consultants and residents, speaks about the anxiety of the socioenvironmental situation of the Ulytau district of the Karaganda region, which is also correlated with our data. He notes that Baikonur is the oldest, largest, and now the busiest space complex in the world, operating continuously since the beginning of the Soviet program since 1957. Almost 300 of the 428 Russian launches between January 2001 and October 2017 left Baikonur. Ecological damage from toxic precipitation over the past fifty years (out of thirty known fall zones) reaches 3,000 square kilometers and covers part of the Karaganda, Pavlodar, Akmola, and East Kazakhstan regions (Baikonur Agreement, 2005). Due to over 2,000 total launches and estimates, more than 27,000 square miles of land was described by international observers as "areas of environmental crisis or "zones of environmental disaster” (UNDP, 2004, 51) (Kopack, 2019).

The first systemic shortcomings in security management, caused by the cultural and political values occurred on 24 October 1960 at the Baikonur launching area in the USSR. An electrical problem led to the deadliest accident in the history of the space industry. Shortly before the test launch of the first Soviet intercontinental P-16 rocket, the second-stage engines ignited prematurely, blowing up the first-stage fuel tanks (Gingerich et al., 2015).

Currently, there is being conducted an analysis "Study of the danger of the system launching" for new launch vehicles of various manufacturers and original industrial organizations. This analysis includes a description of all hazards associated with the operation in normal and accidental situations. For example, since 2010, each new design of a European launch vehicle has required a hazard analysis (Delorme and Biard, 2016; Pelton, 2016; Trushlyakov and Shatrov, 2017).

\section{CONCLUSIONS}

The crash of the Proton-M carrier rocket caused disturbance of the soil and vegetation cover, ignition of vegetation, and soil contamination with UDMH in the area where rocket parts crashed with its content 1.4 to 5,200 times higher than TLV $(0.1 \mathrm{mg} / \mathrm{kg})$.

The consequences of the carrier rocket crash increased the area of UDMH soil and vegetation contamination up to $3,600 \mathrm{~m}^{2}$, NDMA contamination to $917 \mathrm{~m}^{2}$, and nitrate ions contamination to $8,314 \mathrm{~m}^{2}$;

After repeated soil detoxification using potassium permanganate, the reappearance of heptyl and nitrous compounds in plants and soil was detected after four years. 


\section{Acknowledgements}

This study was carried out as a part of the project on the budget program 217 "Development of science" of the Ministry of Education and Science of the Republic of Kazakhstan for 2018-2020. No. AP05130808 on the topic: The impact of the consequences of "Proton-M" rocket carrier (launch vehicles) launches on the environment and the development of methods for detoxification.

\section{REFERENCES}

1. Barmin I.V., Neustroev V.N., Lebedeva L.I. 2018. Problems of ground safety supporting at launch of space vehicle with manned spacecraft. Acta Astronautica, 150, 6-14. https://doi.org/10.1016/j. actaastro.2017.12.008

2. Bolodyan I.A., Melikhov A.S., Tanklevskiy L.T. 2018. Analysis of statistical data about design of firesafe materials in oxygen-rich atmosphere of inhabited pressurized compartments of Russian manned spacecraft. Acta Astronautica, 150, 137-143. https:// doi.org/10.1016/j.actaastro.2017.10.019.

3. Cohen A., McCarthy J. 2015. Reviewing rescaling: Strengthening the case for environmental considerations. Progress in Human Geography, 39(1), 3-25. https://doi.org/10.1177/0309132514521483

4. Dek C., Overkamp J.L., Toeter A., Hoppenbrouwer T., Slimmens J., Zijl J., Rossi P.A., Machado R., Hereijgers S., Kilic V., Naeije M. 2020. A recovery system for the key components of the first stage of a heavy launch vehicle. Aerospace Science and Technology, 100, 105778 .https://doi.org/10.1016/j. ast.2020.105778

5. Delorme D., Biard A. 2016 Launch System Hazard Study: Methodology and Lessons Learnt after 5 years of Application. Journal of Space Safety Engineering, 3(2), 94-100. https://doi.org/10.1016/ S2468-8967(16)30024-6.

6. Federal Aviation Administration. 2016. The annual compendium of commercial space transportation: 2016. Available at: https://www.faa.gov/about/ office_org/headquarters_offices/ast/media/2016_ compendium.pdf (Accessed June 16, 2020).

7. Gingerich D.E., Forrest J.S., Abiin A.A., Maricle-Fitzpatrick T.M. 2015. The Russian R-16 Nedelin Disaster: An Historical Analysis of Failed Safety Management. Journal of Space Safety Engineering 2(2), 65-73. https://doi.org/10.1016/ S2468-8967(16)30052-0

8. Gruntman M. 2019. From Tyuratam Missile Range to Baikonur Cosmodrome. Acta
Astronautica, 155, 350-366. https://doi. org/10.1016/j.actaastro.2018.12.021

9. Huang D., Liu X., Wang X., Zuo C., Xie Z., Gao $X .2019$. The competitive formation mechanism of $\mathrm{N}$-nitrosodimethylamine and formaldehyde dimethylhydrazone from 1,1-dimethylhydrazine during ozonation in air: A combined theoretical and experimental study. Chemical Physics 522, 220-227. https://doi.org/10.1016/j.chemphys.2019.01.011

10. Kopack R.A. 2019. Rocket Wastelands in Kazakhstan: Scientific Authoritarianism and the Baikonur Cosmodrome. Annals of the American Association of Geographers, 109(2), 556-567. https://doi.org/1 $0.1080 / 24694452.2018 .1507817$

11. Koroleva T.V., Kondratev A.V., Krechetov P.P., Semenkov I., Sharapova A.V., Chernitsova O.V. 2015. Improvement of Ecological Characteristics of the Space-Rocket Hardware and Monitoring of Its Environmental Effect on the Surrounding Medium. [Sovershenstvovaniye ekologicheskikh kharakteristik raketno-kosmicheskoy tekhniki i monitoring yeye vozdeystviya na okruzhayushchuyu sredu]. Ecology and Industry of Russia 19(6), 17-23. https:// doi.org/10.18412/1816-0395-2015-6-17-23

12. Kosyakov D.S., Ul'yanovskii N.V., Ivakhnov A.D., Pikovskoi I.I. 2019. Transformation of Unsymmetrical Dimethylhydrazine in Supercritical Wate. Russ. J. Phys. Chem. B., 13, 1103-1110. https://doi. org/10.1134/S1990793119070157.

13. Liao X., Bai X., Qi H., Li F., Yuan B. 2019. New perspective of Br-'s role on NDMA formation from daminozide (DMNZD) during ozonation. Science of The Total Environment 696, 133892. https://doi. org/10.1016/j.scitotenv.2019.133892

14. Maikanov B.S., Auteleyeva L.T. 2018. Amino-Acid Composition of a Cow Milk from the Farms that Are Adjacent to Zones of a Falling of Rocket Carrier 'Proton-M'. Science Bulletin of S.Seifullin Kazakh Agrotechnical University, 2(97), 126-139. Available at: http://bulletinofscience.kazatu.kz/assets/i/ journals/2(97)2018/\%D0\%9C\%D0\%B0\%D0\%B9 $\% \mathrm{D} 0 \% \mathrm{BA} \% \mathrm{D} 0 \% \mathrm{~B} 0 \% \mathrm{D} 0 \% \mathrm{BD} \% \mathrm{D} 0 \% \mathrm{BE} \% \mathrm{D} 0 \% \mathrm{~B}$ $2 . \% \mathrm{D} 0 \% 91 . \% \mathrm{D} 0 \% \mathrm{~A} 1 . \mathrm{pdf}$

15. Milyushkin A.L., Birin K.P., Matyushin D.D., Semeikin A.V., Iartsev S.D., Karnaeva A.E., Uleanov A.V., Buryak A.K. 2019. Isomeric derivatives of triazoles as new toxic decomposition products of 1,1-dimethylhydrazine. Chemosphere, 217, 95-99. https://doi.org/10.1016/j.chemosphere.2018.10.155

16. Pelton J.N. 2016. A new space safety mandate for the worlds space agencies. Journal of Space Safety Engineering, 3(3), 102-103. https://doi.org/10.1016/ S2468-8967(17)30001-0

17. Pohanish R.P. 2017. Sittig's Handbook of Toxic and Hazardous Chemicals and Carcinogens. 7th Ed. Chennai: Elsevier. 
18. Ruzmetova E.A., Plaksitsky A.B. 2017. Methodology for estimating costs for emergency Launches of the Proton- $\mathrm{M}$ rocket carrier safety problems in emergency response [Metodika otsenki zatrat na avariynyye puski rakety-nositelya 'Proton-M'. Problemy bezopasnosti pri avariynom reagirovanii]. Voronezh, 1, 938-943. https://www.elibrary. ru/download/elibrary_37158269_95789163.pdf

19. Sharifivash R., Shokrpour M. 2017. Physico-Chemical Evaluation of Some Wormwood (Artemisia absinthium L.) Ecotypes Under Salt Stress Condition. Journal of Plant Physiology and Breeding, 7(2), 8190. https://breeding.tabrizu.ac.ir/article_8000.html

20. Trushlyakov V., Shatrov Y. 2017. Improving of technical characteristics of launch vehicles with liquid rocket engines using active onboard de-orbiting systems. Acta Astronautica, 138, 19-27. https://doi. org/10.1016/j.actaastro.2017.05.018

21. Trushlyakov V., Shatrov Ya., Sujmenbaev B., Baranov D. 2016. The designing of launch vehicles with liquid propulsion engines ensuring fire, explosion and environmental safety requirements of worked-off stages. Acta Astronautica, 131, 96-101. https://doi.org/10.1016/j.actaastro.2016.11.031
22. Ul'yanovskii N.V., Lakhmanov D.E., Pikovskoi I.I., Falev D.I., Popov M.S., Kozhevnikov A.Y., Kosyakov D.S. 2020. Data on the spatial distribution of 1,1-dimethylhydrazine and its transformation products in peat bog soil of rocket stage fall site in Russian North. Data in Brief 30, 105614. https://doi. org/10.1016/j.dib.2020.105614

23. Ul'yanovskii N.V., Lakhmanov D.E., Pikovskoi I.I., Falev D.I., Popov M.S., Kozhevnikov A.Y., Kosyakov D.S. 2020. Migration and transformation of 1,1-dimethylhydrazine in peat bog soil of rocket stage fall site in Russian North. Science of the Total Environment, 726, 138483. https://doi. org/10.1016/j.scitotenv.2020.138483

24. Veniaminov S., Klyushnikov V., Kozlov S., Nagorskiy P. 2018. Launch malfunctions and space weather factors. Acta Astronautica, 150, 33-38. https://doi. org/10.1016/j.actaastro.2017.10.039

25. Zarei A.R., Rezaeivahidian H., Soleymani A.R. 2016. Mineralization of unsymmetrical dimethylhydrazine (UDMH) via persulfate activated by zero valent iron nano particles: modeling, optimization and cost estimation. Desalination and Water Treatment, 57, 16119-16128. https://doi.org/10.1080/19 443994.2015.1077747 